$1+\mathrm{HF} / \mathrm{AsF}_{5} \longrightarrow\left[\mathrm{HNSF}_{2} \mathrm{NMe}_{2}\right]^{\oplus} \mathrm{AsF}_{6}^{\ominus} 5$

$\mathrm{NSF}_{3}+\mathrm{HF} / \mathrm{AsF}_{5} \longrightarrow\left[\mathrm{F}_{5} \mathrm{~S}-\mathrm{NH}_{3}\right]^{\oplus} \mathrm{AsF}_{6}^{\ominus} \quad 6$

In contrast, $\mathrm{NSF}_{3}$ reacts with $\mathrm{HF} / \mathrm{AsF}_{5}$ to afford the stable and isolable pentafluorosulfanylammonium salt $6^{[12,14]}$. The dimethylamino group in $\mathbf{5}$ reduces the electrophilicity of the central sulfur atom to such an extent that $\mathrm{F}^{\ominus}$ can no longer add to increase the coordination number; in this way, all subsequent steps to a product analogous to 6 are blocked.

The salts 3 are stable, colorless solids (m.p. $=101^{\circ} \mathrm{C}$ (3a), $\left.103^{\circ} \mathrm{C}(\mathbf{3 b})\right)$ that are readily attacked by nucleophiles, e.g. $\mathrm{H}_{2} \mathrm{O}$ or $\mathrm{X}^{\ominus}$ of $\mathrm{NaCl}-$ and $\mathrm{KBr}-\mathrm{IR}$ plates. They were characterized by elemental analysis and by IR and NMR spectroscopy (Table 1). Bands at 945 and $910 \mathrm{~cm}^{-1}$ in the IR spectrum are assigned to the $v_{\text {as }}(\mathrm{SF})$ and $v_{\mathrm{sym}}(\mathrm{SF})$ vibrations.

Table 1. NMR data of salts 3 and 5 [a] as well as the neutral $S^{\text {IV }}$ derivative $\left(\mathrm{Me}_{2} \mathrm{~N}\right)_{2} \mathrm{SF}_{2}[13]$

\begin{tabular}{llllll}
\hline & $\begin{array}{l}{ }^{19} \mathrm{~F} \mathrm{[a]} \\
\delta\left(\mathrm{SF}_{2}\right)\end{array}$ & $\begin{array}{l}{ }^{1} \mathrm{H} \\
\delta\left(\mathrm{CH}_{3}\right)\end{array}$ & $\begin{array}{l}{ }^{13} \mathrm{C}[\mathrm{b}] \\
\delta\left(\mathrm{CH}_{3}\right)\end{array}$ & ${ }^{4} J_{\mathrm{H} F}[\mathrm{~Hz}]$ & ${ }^{3} J_{\mathrm{FC}}[\mathrm{Hz}]$ \\
\hline $\mathbf{3 a}$ & $38.6[\mathrm{c}]$ & $4.20(\mathrm{t})$ & $48.19(\mathrm{t})$ & 4.75 & 2.1 \\
$\mathbf{3 b}$ & $37.9[\mathrm{cl}$ & $4.22(\mathrm{t})$ & $48.21(\mathrm{t})$ & 4.80 & 2.1 \\
$\mathbf{5}$ & 54.7 (sept.) & $3.16(\mathrm{t})$ & & 2.89 & \\
& & $(\mathrm{~N}-\mathrm{H} \mathrm{7.37)}$ & & & \\
$\left(\mathrm{Me}_{2} \mathrm{~N}_{2} \mathrm{SF}_{2}\right.$ & $7.5($ br. s) & $2.72(\mathrm{br} . \mathrm{s})$ & $37.71(\mathrm{~s})$ & - & - \\
\hline
\end{tabular}

[a] ${ }^{19} \mathrm{~F}$-NMR (3a, 3b: $60 \mathrm{MHz}, \mathrm{SO}_{2}, 301 \mathrm{~K} ; 5: 75.4 \mathrm{MHz}, \mathrm{SO}_{2}, 253 \mathrm{~K}$ ), ${ }^{13} \mathrm{C}$ NMR (20.15 MHz, SO, $309 \mathrm{~K}),{ }^{1} \mathrm{H}-\mathrm{NMR}\left(80.13 \mathrm{MHz}, \mathrm{SO}_{2}, 304 \mathrm{~K}\right)$. [b] Proton decoupled. [c] Of the 13 lines expected only 11 were observed.

The NMR data for the cations of salts 3 and 5 as well as the neutral $\mathrm{S}^{\mathrm{IV}}$ derivative $\left(\mathrm{Me}_{2} \mathrm{~N}\right)_{2} \mathrm{SF}_{2}^{[13]}$ are shown in Table 1 ; nevertheless, a direct comparison of the cations with the neutral compound is not without problems since in this the sulfur atom has trigonal-bipyramidal coordination, but in the cation the sulfur atom is tetrahedral. The nature of the anion in $\mathbf{3}$ does not influence the spectroscopic data of the dication; no interaction therefore appears to be present in solution.

Received: March 5, 1984; revised: May 14, 1984 [Z 743 IE] German version: Angew. Chem. 96 (1984) 509

[1] R. S. Michalak, J. C. Martin, J. Am. Chem. Soc. 102 (1980) 5921

[2] G. Kleemann, K. Seppelt, Angew. Chem. 93 (1981) 1096; Angew. Chem. Int. Ed. Engl. 20 (1981) 1037.

[3] F. Seel, G. Detmer, Angew. Chem. 70 (1958) 163; Z. Anorg. Allg. Chem. 301 (1959) 113

[4] a) R. Mews, Adv. Inorg. Chem. Radiochem. 19 (1976) 185; b) R. Mews, H. Henle, J. Fiuorine Chem. 14 (1979) 495.

[5] C. Lau, J. Passmore, J. Chem. Soc. Chem. Commun. 1971, 950; J. Chem. Soc. Dalton Trans. 1973, 2528.

[6] a) R. Mews, Angew. Chem. 90 (1978) 561; Angew. Chem. Int. Ed. Engl. $17(1978) 530$; b) H. Henle, Dissertation, Universität Göttingen 1981; c) R. Bartsch, Diplomarbeit, Universität Göttingen 1980.

[7] A. H. Cowley, D. J. Pagel, M. L. Walker, J. Am. Chem. Soc. 100 (1978) 7065

[8] A. H. Cowley, D. J. Pagel, M. L. Walker, J. Chem. Soc. Chem. Commun. $1979,965$.

[9] G. A. Olah, D. J. Donovan, H. C. Lin, J. Am. Chem. Soc. 98 (1976) 2661; P. E. Peterson, R. Brockington, D. W. Vidrine, ibid. 98 (1976) 2660; R. J. Gillespie, F. G. Riddell, D. R. Slim, ibid. 98 (1976) 8069.

[10] 4a: ${ }^{19} \mathrm{~F}-\mathrm{NMR}\left(60 \mathrm{MHz}, \mathrm{SO}_{2}\right.$, stand. $\left.\mathrm{CFCl}_{3}\right): \delta=54.75$ (br. s, SF), -33.75 (br. s, AsF); ${ }^{1} \mathrm{H}-\mathrm{NMR}\left(60 \mathrm{MHz}, \mathrm{SO}_{2}\right.$, stand. TMS): $\delta=3.47$ (t, $\left.J(\mathrm{HF})=2.7 \mathrm{~Hz}, \mathrm{CH}_{3}\right) ; 4 \mathrm{~b}:{ }^{19} \mathrm{~F}-\mathrm{NMR}\left(60 \mathrm{MHz}, \mathrm{SO}_{2}\right.$, stand. $\left.\mathrm{CFCl}_{3}\right)$ : $\delta=56.97$ (sept., SF); 'H-NMR (60 MHz, $\mathrm{SO}_{2}$, stand. TMS): $\delta=3.48$ (t, $J(\mathrm{HF})=2.65 \mathrm{~Hz}, \mathrm{CH}_{3}$ ) (A. Waterfeld, Diplomarbeit, Universität Göttingen 1977)
[11] 2a: ${ }^{19} \mathrm{~F}-\mathrm{NMR}\left(60 \mathrm{MHz}, \mathrm{SO}_{2}, \mathrm{CFCl}_{3}\right): \delta=54.5$ (SF): ${ }^{\mathrm{i}} \mathrm{H}-\mathrm{NMR}(60 \mathrm{MHz}$, $\left.\mathrm{SO}_{2}, \mathrm{TMS}\right): \delta=3.60\left(J\left(\mathrm{~F}-\mathrm{CH}_{3}\right)=7.7 \mathrm{~Hz}, \mathrm{CH}_{3}\right), 3.48\left(J\left(\mathrm{~F}-\left(\mathrm{CH}_{3}\right)_{2}\right)=2.5\right.$ $\left.\mathrm{Hz},\left(\mathrm{CH}_{3}\right)_{2}\right)$ [6c]; 2b: ${ }^{19} \mathrm{~F}-\mathrm{NMR}\left(60 \mathrm{MHz}, \mathrm{SO}_{2}, \mathrm{CFCl}_{3}\right): \delta=54.4$ (SF); ${ }^{1} \mathrm{H}-\mathrm{NMR}\left(60 \mathrm{MHz}, \mathrm{SO}_{2}, \mathrm{TMS}\right): \delta=3.53\left(\mathrm{~J}\left(\mathrm{~F}-\mathrm{CH}_{3}\right)=7.8 \mathrm{~Hz}, \mathrm{CH}_{3}\right), 3.44$ $\left(J\left(\mathrm{~F}-\left(\mathrm{CH}_{3}\right)_{2}\right)=2.6 \mathrm{~Hz},\left(\mathrm{CH}_{2}\right)\right.$

[12] NMR data for 6: ${ }^{19} \mathrm{~F}-\mathrm{NMR}\left(235.35 \mathrm{MHz}, \mathrm{SO}_{2}\right.$, stand. $\left.\mathrm{CFCl}_{3}\right): \delta=76.37$ $\left({ }^{2} J(\mathrm{~F}-\mathrm{F})=156.5 \mathrm{~Hz}, \mathrm{SF}_{4}\right), 52.43(\mathrm{SF}) ;{ }^{1} \mathrm{H}-\mathrm{NMR}\left(60 \mathrm{MHz}, \mathrm{SO}_{2}\right.$, stand. TMS): $\delta=8.8(\mathrm{NH})$. The $1: 1$ compound $\mathrm{SF}_{5} \mathrm{NH}_{2} \cdot \mathrm{HCl}$ can be obtained at $-78^{\circ} \mathrm{C}$, but at room temperature decomposes into its components: $\mathrm{J}$. S. Thrasher, K. Seppelt, Z. Anorg. Allg. Chem. 507 (1983) 7. Analogous structural and bonding behavior are expected for 6 as for the recently described isoelectronic $\mathrm{F}_{5} \mathrm{P}-\mathrm{NH}_{3}$ (W. Storzer, D. Schomburg, G.-V. Röschenthaler, R. Schmutzler, Chem. Ber. 116 (1983) 367). The ${ }^{2} J\left(\mathrm{~N}-\mathrm{F}_{4}\right)$ coupling observed in $\mathrm{F}_{5} \mathrm{P}-\mathrm{NH}_{3}$ is not found in 6.

[13] A. H. Cowley, P. E. Riley, J. S. Szobota, M. C. Walker, J. Am. Chem. Soc. 101 (1979) 5620

[14] General Procedure: 3: $\mathrm{SO}_{2}(5-10 \mathrm{~mL})$ is condensed onto $2-3 \mathrm{mmol}$ $M F_{5}$ (a: $M=A s ; b: M=S b$ ) and $\mathrm{CH}_{3} F$ (slight excess); the mixture is warmed slowly to $-30^{\circ} \mathrm{C}$ and held at this temperature for $2-3 \mathrm{~h}$ until formation of (MeOSO) ${ }^{\oplus} \mathrm{MF}_{6}^{6}$ is complete. The solution is then cooled again to $-196^{\circ} \mathrm{C}$ and 1 condensed in; the mixture is warmed slowly to room temperature and stirred for $2 \mathrm{~d}$. After removal of the solvent $3 \mathrm{a}$ and $\mathbf{3 b}$ are isolated in quantitative yield as analytically pure solids. $-\mathbf{5}$ and 6: $5 \mathrm{~mL} \mathrm{HF}$ and $\mathrm{MeF}_{5}$ are condensed into a cold trap (Kel-F) containing 1-2 mmol 1 or $\mathrm{NSF}_{3}$ (molar ratio $\mathrm{NSF}_{3}: \mathrm{AsF}_{5}<1: 2$ ) at $-196^{\circ} \mathrm{C}$. After removal of the volatile products, 5 and 6 remain as almost analytically pure substances. Purer products can be obtained by dissolving the Lewis acid adducts $\mathrm{F}_{5} \mathrm{M} \cdot \mathrm{N}=\mathrm{SF}_{2}(\mathrm{NMe})_{2}$ or $\mathrm{MF}_{5}-\mathrm{NSF}_{3}$ in HF.

\section{A Facile Route to Benzoannelated Centrotriquinanes}

\section{By Dietmar Kuck*}

Centropolyquinanes ${ }^{[1]}$ are a fascinating group of compounds, which, as polycondensed cyclopentane hydrocarbons, have been intensively studied in recent years ${ }^{[2-4]}$. They are characterized by a central $\mathrm{C}$ atom shared by all cyclopentane rings. The centrohexaquinane (" $\mathrm{C}_{17}$-hexaquinane") 1 represents a challenging synthetic target molecule $e^{[s]}$.
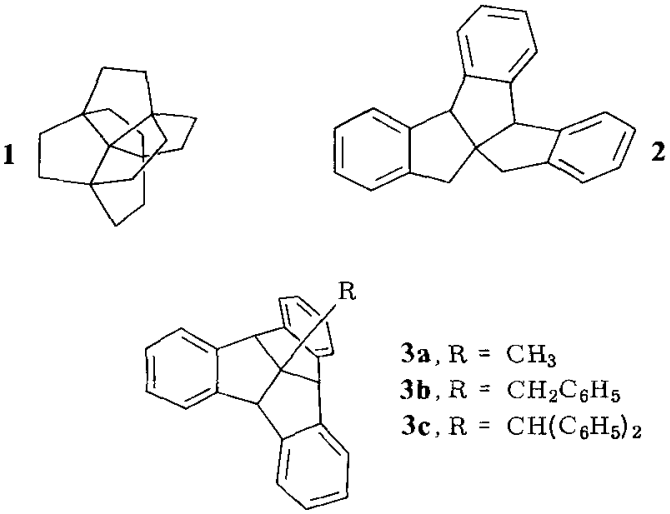

We report here a facile synthesis of benzoannelated centrotriquinanes of type 2 and $3^{[6]}$, which can be used as educts for the synthesis of higher centropolyquinanes. Key reaction in the synthesis is the double cyclodehydration of the 2,2-disubstituted 1,3 -indanediols 5 , which can readily be prepared by reduction of the corresponding 1,3-indanediones 4.

Whereas the tribenzotricyclo[6.3.0.0 $\left.0^{1,5}\right]$ undecane 2 is obtained in excellent yield ${ }^{[14]}$, the 10 -alkyltriben-

[*] Dr. D. Kuck

Fakultät für Chemie der Unjversität

Postfach 8640, D-4800 Bielefeld I (FRG) 
<smiles>[R]C1([R])C(=O)c2ccccc2C1=O</smiles>

4<smiles>O=Cc1ccccc1/C=C\Cc1ccccc1</smiles>

5

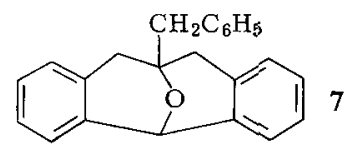

zo[5.2.1. $\left.0^{4,10}\right]$ decanes 3 have, up till now, only been accessible in moderate yields (Table 1). We attribute this to the prochirality of the benzhydryl group and, in particular, to the susceptibility of the 1,3-diol system to cleavage under acidic conditions. Moreover, the ring opening is certainly favored by the steric hindrance of the quaternary center. Of greater note therefore is the double cyclization, specifically of $5\left(\mathrm{R}^{1}=\mathrm{R}^{2}=\mathrm{CH}\left(\mathrm{C}_{6} \mathrm{H}_{5}\right)_{2}\right)$ to $3 c$, whose structure, like those of other centrotriquinanes, is consistent with the spectroscopic data (Table 1) $)^{[7]}$.

Table 1. Centrotriquinanes 2 and $3 a-3 c$. Yields, melting points, and some ${ }^{1} \mathrm{H}$ - and ${ }^{13} \mathrm{C}-\mathrm{NMR}$ data (in parentheses) [a].

\begin{tabular}{lllllll}
\hline & $\begin{array}{c}\text { Yield } \\
{[\%]}\end{array}$ & $\begin{array}{c}\text { M.p. } \\
{\left[{ }^{\circ} \mathrm{C}\right]}\end{array}$ & $\mathrm{C}($ quart $)$ & $\mathrm{C}($ tert $)$ & $\begin{array}{c}\text { NMR Data } \\
\mathrm{C}(\text { sec })\end{array}$ & $\mathrm{C}_{\boldsymbol{\alpha}}(\mathrm{R})$ \\
\hline 2 & 92 & 148 & $(62.8)$ & $4.44(62.1)$ & $3.15[\mathrm{~b}](44.5)$ & - \\
& & & & & $3.34[\mathrm{~b}]$ & \\
3a & 33 & 239 & $(60.7)$ & $4.47(63.7)$ & - & $1.68(27.6)$ \\
3b & 18 & 243 & $(65.2)$ & $4.80(61.3)$ & - & $3.33(45.7)$ \\
3c & 26 & 318 & $(68.7)$ & $5.10(60.8)$ & - & $4.60(59.7)$
\end{tabular}

[a] $80(300) \mathrm{MHz}, \delta$ in $\mathrm{CDCl}_{3}$. The number of signals from the aromatic groups as well as the integrated intensities and multiplicities reflect the symmetry of the compounds. [b] ${ }^{2} J=-16.4 \mathrm{~Hz}$.

Under relatively mild conditions (e.g. $p$ - $\mathrm{CH}_{3} \mathrm{C}_{6} \mathrm{H}_{4} \mathrm{SO}_{3} \mathrm{H} /$ $\mathrm{C}_{6} \mathrm{H}_{6}$ ) predominantly products of ring-opening form, e.g. compounds 6 and $7^{[8]}$. However, under conditions of acid catalysis, $\mathbf{6}$ is converted into a mixture of 7 and 2. It can therefore be assumed that the tricycles 2 and 3 are, at least in part, formed via acyclic intermediates of type 6. In the UV spectra ${ }^{[9]}$ of the tribenzocentrotriquinanes 3 , which have $C_{3 v}$ symmetry, the $\alpha$-bands display a slight bathochromic shift relative to indane ${ }^{[10]}\left(\Delta \lambda_{\max }=2.0-3.5 \mathrm{~nm}\right)$ and have a threefold greater molar extinction in each case. In contrast, this effect is absent in $2\left(\Delta \lambda_{\max }<0.5 \mathrm{~nm}\right)$. Extensive interactions between the benzene chromophores are therefore-as in other centrotriquinanes of this type ${ }^{[6]}$-not present.

Received: March 7, 1984; revised: May 18, 1984 [Z 748 IE] German version: Angew. Chem. 94 (1984) 515

[1] P. Gund, T. M. Gund, J. Am. Chem. Soc. 103 (1981) 4456.

[2] L. A. Paquette, Top. Curr. Chem. 79 (1979) 41 ; ibid. 119 (1984) 1.

[3] P. E. Eaton, Tetrahedron 35 (1979) 2189.

[4] B. M. Trost, Chem. Soc. Rev. 1982, 141

[5] H. E. Simmons, III, J. E. Maggio, Tetrahedron Lett. 22 (1981) 287; L. A. Paquette, M. Vazeux, ibid. 22 (1981) 291.

[6] Two other triply benzoannelated centrotriquinanes have previously been described: H. W. Thompson, J. Org. Chem. 33 (1968) 621; W. Ten Hoeve, H. Wynberg, ibid. 45 (1980) 2930.

[7] The elemental analyses and mass spectra of all compounds corroborate the compositions given.
[8] 6: M.p. $=64-65^{\circ} \mathrm{C}$ (petroleum ether); 'H-NMR (80 MHz, $\mathrm{CDCl}_{3}$ / TMS): $\delta=3.35(\mathrm{~s}, 2 \mathrm{H}), 3.44(\mathrm{~d}, 1.2 \mathrm{~Hz}, 2 \mathrm{H}), 6.81(\mathrm{br}, \mathrm{s}, 1 \mathrm{H}), 6.95-7.70$ $(\mathrm{m}, 13 \mathrm{H}), 7.90(\mathrm{~m}, 1 \mathrm{H}), 10.30(\mathrm{~s}, 1 \mathrm{H}) ; \mathrm{IR}(\mathrm{KBr}): \bar{v}\left[\mathrm{~cm}^{-1}\right]=2830(\mathrm{w})$ $2730(w), 1685(\mathrm{~s}) ; \mathrm{MS}(70 \mathrm{eV}): m / z 312\left(M^{\oplus}, 0.2 \%\right), 221\left(M^{\oplus}-\mathrm{C}_{7} \mathrm{H}_{7}\right.$ $100), 115\left(\mathrm{C}_{9} \mathrm{H}_{7}^{\oplus}, 28\right), 91\left(\mathrm{C}_{7} \mathrm{H}_{7}^{\oplus}, 81\right)-7:$ M.p. $=112-113^{\circ} \mathrm{C}\left(\mathrm{C}_{2} \mathrm{H}_{5} \mathrm{OH}\right)$ 'H-NMR (80 MHz, $\left.\mathrm{CDCl}_{3} / \mathrm{TMS}\right): \delta=2.62,3.17(\mathrm{AB},-16.6 \mathrm{~Hz}, 4 \mathrm{H})$, $3.10(\mathrm{~s}, 2 \mathrm{H}), 5.79(\mathrm{~s}, 1 \mathrm{H}), 6.9-7.5(\mathrm{~m}, 13 \mathrm{H})$; IR (KBr): $\bar{v}=2840(\mathrm{w})$, $1190(\mathrm{~s}), 1080(\mathrm{~s}), 1070(\mathrm{~s}), 1030(\mathrm{~s}) ; \mathrm{MS}(70 \mathrm{eV}): \mathrm{m} / z 312\left(M^{\oplus}, 59\right), 221$ $\left(M^{\oplus}-\mathrm{C}_{7} \mathrm{H}_{7}, 67\right), 220\left(M^{\oplus}-\mathrm{C}_{7} \mathrm{H}_{8}, 54\right), 193(82), 179(100), 178(80), 91$ $\left(\mathrm{C}_{7} \mathrm{H}_{7}^{\oplus}, 96\right)$.

[9] UV spectra ( $n$-hexane, $c=4 \times 10^{-4}$ to $4 \times 10^{-5} \mathrm{~mol} \mathrm{~L}^{-1}$ ): $2: \lambda$ $[\mathrm{nm}]=274.0(\varepsilon=4540), 267.5(3840), 261.0(2310) ; 3 \mathrm{a}: 276.0(4570), 269.0$ (3780), 263.5 (2350); 3b: $276.3(4620), 269.2(4120), 263.0(2850) ; 3 c$ : 276.8 (4410), 269.7 (4080), $263.5(3010)$.

[10] American Petroleum Institute (API). Research Project 44/II (1950) 400, (1951) 414.

[11] D. Radulescu, I. Tanasescu, Bulet. Soc. Stiinte Cluj 1 (1922) 185; Chem. Zentralbl. 94/III (1923) 137.

[12] R. Bloch, P. Orvane, Synth. Commun. 11 (1981) 913.

[13] M.p. $=104-105^{\circ} \mathrm{C}$ (congealed oil); ' $\mathrm{H}-\mathrm{NMR}\left(80 \mathrm{MHz}, \mathrm{CDCl}_{3} / \mathrm{TMS}\right.$ ): $\delta=1.30(\mathrm{~d}, 5.1 \mathrm{~Hz}, 2 \mathrm{OH}), 2.87,2.99(\mathrm{AB},-14.1 \mathrm{~Hz}, 4 \mathrm{H}), 5.18(\mathrm{~d}, 5.1$ $\mathrm{Hz}, 2 \mathrm{H}), 7.26(\mathrm{~m}, 13 \mathrm{H})$; IR (KBr): $\bar{v}\left[\mathrm{~cm}^{-1}\right]=3590(\mathrm{~m}), 3430(\mathrm{~s})$.

[14] Procedure: $2: 2,2$-Dibenzyl-1,3-indanedione 4 [11] is obtained in quantitative yield from 1,3-indanedione and benzyl bromide with $\mathrm{KF}$ /celite 545 (Fluka) in $\mathrm{CH}_{3} \mathrm{CN}$, by analogy to a procedure described by Bloch and Orvane [12], and reduced with $\mathrm{LiAlH}_{4}$ in tetrahydrofuran (THF) using standard methods to afford the trans-1,3-diol $5\left(\mathrm{R}^{1}=\mathrm{R}^{2}=\mathrm{CH}_{2} \mathrm{C}_{6} \mathrm{H}_{5}\right)$ [13] (crude yield quantitative). - A solution of this diol $(3.3 \mathrm{~g}, 10 \mathrm{mmol})$ in $120 \mathrm{~mL}$ xylene is refluxed with $85 \% \mathrm{H}_{3} \mathrm{PO}_{4}(1.6 \mathrm{~g})$ for ca. $15 \mathrm{~h}$ in a water separator. The reaction solution is then washed with dilute $\mathrm{Na}_{2} \mathrm{CO}_{3}$ solution and water and dried over $\mathrm{Na}_{2} \mathrm{SO}_{4}$. After removal of the solvent an oil is formed from which 2 is obtained as fine, white needles by recrystallization from EtOH.

\section{1,2,3-Benzoxadiazole- Detection in an Argon Matrix and in Solution**}

By Reinhard Schulz and Armin Schweig*

The notion that compounds such as 1 with 1,2,3-oxadiazole structures are not capable of existing ${ }^{[1,2]}$ was refuted for the first time by PE spectroscopic studies on 6-diazo2,4-cyclohexadienone $2^{[3]}$. We report here independent experiments in a noble gas matrix and in solution which corroborate the presence of an equilibrium between 1,2,3-benzoxadiazole 1 and 6-diazo-2,4-cyclohexadienone 2 , and remove any doubts ${ }^{[4]}$ surrounding our previous work ${ }^{[3]}$.<smiles>O=C1C=CC=CC1=[W]</smiles>

If -as indicated by the results of $\mathrm{PE}$ spectroscopy-the diazoquinone 2 and the oxadiazole 1 both exist in the gas phase, it should be possible to freeze out both components at low temperature. The condensate formed from condensation of diazocyclohexadienone vapor 2 (vaporized at room temperature and ca. $4 \times 10^{-2}$ mbar) and excess argon in a vacuum flow system at $15 \mathrm{~K}$ exhibits intense IR absorptions originating from a compound, which, even during recording of the spectrum, is re-converted into 2 . This retro-isomerization cannot only be followed by IR spectroscopy, but also by the naked eye due to a marked deepening of the color of the originally light yellow matrix $\left(\lambda_{\max }\right.$ of 2 in hexane: $407 \mathrm{~nm}$ ). The IR-induced isomerization to 2 at $15.4 \mathrm{~K}$ exactly follows first-order kinetics $\left(\tau_{1 / 2}=6.2 \mathrm{~min}\right)$. By inserting a filter which transmits only

[*] Prof. Dr. A. Schweig, Dr. R. Schulz

Fachbereich Physikalische Chemie der Universität Hans-Meerwein-Strasse, D-3550 Marburg (FRG)

[**] This work was supported by the Deutsche Forschungsgemeinschaft and by the Fonds der Chemischen Industrie. 